\title{
Using MaxEnt modeling to predict the potential distribution of Platyrrhinus ismaeli (Phyllostomidae)
}

\author{
Leidy Azucena Ramírez-Fráncel ${ }^{1 *}$, Leidy Viviana García-Herrera ${ }^{1}$, and Gladys Reinoso- Flórez ${ }^{1}$ \\ ${ }^{1}$ Facultad de Ciencias, Grupo de investigación en Zoología, Universidad del Tolima, Colombia. Calle \# 42, Santa Helena parte alta \\ Ibagué-Tolima CP. 546. Colombia. Email: laramirezfr@ut.edu.co (LAR-F), Ivgarcia@ut.edu.co (LVG-H), greinoso@ut.edu.co (GR-F). \\ *Corresponding author
}

\begin{abstract}
The broad-nosed bat, Platyrrhinus ismaeli, is listed as Near Threatened (NT) by the International Union for the Conservation of Nature, and due to the low number of collected specimens, its geographic distribution is poorly known. This study presents the first documented record of this species in the eastern slope of the Colombian Central range. Herein, museum voucher specimens were used as primary sources for the elaboration of a checklist of Platyrrhinus ismaeli from Colombia. In addition, the checklist is supplemented with information on life zones and a potential distribution model for Colombia. This distribution map was used to explore the affinities, in species composition, among Colombian ecoregions as outlined by, and the relationship between associated environmental variables. In total, 15 field-based occurrence points and 20 environmental variables (19 bioclimatic and one topographic) were used to model the potential distribution area. The response curves showed that this species prefers habitats with an annual temperature of 12.0 to $25.5^{\circ} \mathrm{C}$, annual precipitation of 1,000 to $4,000 \mathrm{~mm}$, and an elevation range of 1,200 to 2,850 masl. Most of the current potential suitable conditions were located to the north-center of Colombia. We found that $P$. ismaeli is distributed in Colombia in four main regions, including the Biogeographic Chocó, the Magdalena Valley, the Orinoquia, and the Guianan-Amazon region. The spatial distribution of the species is driven by variables such as temperature, precipitation, and elevation. Changes in these variables affect the normal activities of this species with a narrow geographical niche and dispersal ability may particularly reduce the ability of this species to face global climate change consequences. Therefore, it is imperative to continue exploring the effect of these variables in order to better define the distribution patterns and conservation strategies for this species. Our findings can be used to define high-priority areas for the protection and conservation of $P$. ismaeli.
\end{abstract}

El murciélago de nariz ancha Platyrrhinus ismaeli, está catalogado como Casi Amenazado (NT) por la Unión Internacional para la Conservación de la Naturaleza y, debido a la escasa cantidad de recolectas, su distribución geográfica es poco conocida. Este estudio presenta el primer registro en la vertiente Oriental de los Andes centrales colombianos. Aquí, se utilizaron ejemplares de museo como fuente primaria para generar una lista de verificación de Platyrrhinus ismaeli para Colombia. Además, la lista de verificación está acompañada por las zonas de vida, así como el modelo de distribución potencial para Colombia. Este mapa de distribución se utilizó para investigar las afinidades, en la composición de las especies, entre las ecorregiones colombianas como se describe en, y la relación entre las variables ambientales. En total, se utilizaron 15 puntos de ocurrencia y 20 variables ambientales (19 bioclimáticas y una topográfica) para modelar el área de distribución potencial. Las curvas de respuesta mostraron que esta especie prefiere hábitats con una temperatura anual de 12.0 a $25.5^{\circ} \mathrm{C}$, precipitación anual de 1,000 a 4,000 mm y un rango de elevación de 1,200 a 2,850 m.s.n.m. La mayoría de las posibles condiciones adecuadas actuales se ubicaron en los límites del Centro Norte de Colombia. Descubrimos que $P$. ismaeli se distribuye geográficamente en Colombia en cuatro regiones principales, incluyendo: el Chocó Biogeográfico, el valle del Magdalena, la Orinoquia, y la región de la Guiana-Amazonía. La distribución espacial de la especie depende de variables como la temperatura, la precipitación y la elevación. Estos cambios en estas variables afectan las actividades normales de esta especie con un nicho geográfico estrecho y la capacidad de dispersión puede reducir particularmente la capacidad de esta especie para enfrentar las consecuencias del cambio climático global. Por lo tanto, es importante continuar estudiando el efecto de estas variables para ajustar los patrones de distribución y estrategias de conservación de esta especie. Nuestros hallazgos se pueden usar para definir las áreas de alta prioridad para la protección y conservación de $P$. ismaeli.

Key words: Chiroptera; department of Tolima; distribution; expansion; geographic range; Phyllostomidae.

@ 2020 Asociación Mexicana de Mastozoología, www.mastozoologiamexicana.org

\section{Introduction}

In the Neotropics, bats represent the most diverse group amongst mammals (Vaughan 1997; Medellin et al. 2000; Sampaio et al. 2003; Bracamonte 2011), showing the greatest variety of dietary habits; this flexibility accounts for the morphological, physiological, and ecological complexity of this group (Altringham 2011). Bats of the genus Platyrrhinus (Phyllostomidae) are frugivores that play a key role in seed dispersal and the redistribution of nutrients (Medellin 2003; Velazco and Gardner 2009; Estrada-Villegas et al. 2010).

In recent decades, a number of studies have confirmed the role of this genus in forest succession and ecological restoration, because they consume pioneer species and are among the most important seed dispersers in fragmented and early successional ecosystems (Galindo-González et al. 2000; Marques and Fisher 2009; Castro-Luna and GalindoGonzález 2012; García-Herrera et al. 2019). Therefore, the species of this genus have the potential to provide functional services to the environment because they disperse large amounts of seeds in Neotropical forests.

The genus Platyrrhinus includes 20 recognized species, representing one of the most diverse genera within the family Phyllostomidae (Velazco and Patterson 2008; Velazco and Lim 2014; Velazco et al. 2018), only surpassed 
by the genera Sturnira with 24 species (Velazco and Patterson 2019) and Artibeus with 23 species grouped into two subgenera (Artibeus and Dermanura; Cirranello et al. 2016; Velazco and Patterson 2019). In Colombia, Platyrrhinus is represented by 14 species (Ramírez-Chaves et al. 2016), with geographic and altitudinal ranges that vary widely (Velazco and Solari 2003; Gardner 2008; Velazco and Gardner 2009). As part of the most recent IUCN (International Union for Conservation of Nature) Global Mammal Assessment, three species of Platyrrhinus are listed as Threatened (Platyrrhinus chocoensis, VU, P. ismaeli and P. matapalensis, NT).

Platyrrhinus ismaeli lives mainly in lowland and montane forests (Tirira 2011). The high rate of habitat destruction throughout the tropical Andes may soon cause P. ismaeli to be assigned to the Near Threatened (NT) category (IUCN 2019), thus highlighting the importance of generating in-depth information on the geographic distribution and status of their populations, which is needed to advance conservation actions.

In Colombia, P. ismaeli has been recorded in 26 localities along the Andes (Velazco and Gardner 2009); these include eigth localities in the western range (Departments of Risaralda and Valle del Cauca), nine in the central range (Departments of Antioquia, Cauca, Huila, Putumayo, and Quindío), and nine in the eastern range (Departments of Boyacá, Caquetá, Cundinamarca, Norte de Santander and Meta). Records in Colombian collections support that $P$. ismaeli inhabits a wide variety of habitats within an altitudinal gradient of 1,230 to 2,950 m (Muñoz 2001; Solari et al. 2013). Although this species seemingly prefers high-montane forests (Table 1 ), there are some records of $P$. ismaeli in the foothills of the western range, in the eastern side of the Department of Chocó, suggesting that it also inhabits the premontane very humid forest (Asprilla-Aguilar et al. 2016).

The distribution range reported for this species comprises the eastern slope of the central range (Departments of Nariño and Tolima), the eastern range (Departments of Santander and Casanare), and the low montane forest and low montane wet forest of Colombia (according to Holdridge [1987] system, Table 1), which are highly fragile and threatened ecosystems for impacts related to human activities. Accordingly, we analyzed the potential distribution of $P$. ismaeli, provide cranial measurements and information on the life zones for the new localities (Tables 1, 2, Figure 1, 2, Appendix 1), and discuss the scenarios that might determine the distribution of this species in Colombia. Our objectives were: to predict the current potential distribution, and to identify the key environmental factors that are highly correlated with the distribution range of $P$. ismaeli. This information sets the basis for generating data for the conservation of this species, needed to face the current habitat loss and fragmentation issues, and other impacts to the life zones of populations of this species in Colombia.

\section{Materials and Methods}

The main sources used for this update included research articles, taxonomic revisions, and direct examination of the zoological collections of the University of Tolima (CZUT-M,
Ibagué), Instituto de Investigación de Recursos Biológicos Alexander von Humboldt (IAvH-M, Villa de Leyva), Instituto de Ciencias Naturales at Universidad Nacional de Colombia (ICN, Bogotá), and Universidad del Valle (UV, Cali). Secondary sources include records available in the online databases of the National Museum of Natural History, Smithsonian Institution (NMNH; VertNet), and cataloged specimens reported in regional checklists (for example, Asprilla-Aguilar et al. 2016; Jimenez-Ortega 2013). For specimens to which we had direct access, we took external and cranial measurements with digital calipers to the nearest $0.1 \mathrm{~mm}$ (Table 2). Data on total length (TL) and weight (W) were obtained from specimen labels, recorded at the time of collection.

We reviewed all available specimens housed at the CZUT-M, searching for vouchers of $P$. ismaeli. Based on our review, and because they were suspected of being misidentified, we also included four specimens formerly identified as Vampyrops aurarius (Bejarano-Bonilla et al. 2007), plus another identified as $P$. aurarius by Galindo-Espinosa et al. (2010), and five Chiroderma salvini (identified by GalindoEspinosa et al. 2010). To assess the accuracy of their identifications, we compared each specimen with the characters provided by Velazco (2005) and Velazco and Gardner (2009), and described the morphological characters, external, and cranial and dental measures of $P$. ismaeli distributed in Colombia.

Data sources and selection of variables. In order to elaborate the checklist, we reviewed and gathered occurrence data from $P$. ismaeli records in museum collections in Colombia (CZUT-M, ICN, IAvH-M, UV, and NMNH. Including: coordinates, elevation, locality, geographic region, and life zone according to the classification of Holdridge 1987; Table 1), confirmed by reviewing the morphology and taxonomic identification of specimens (Velazco 2005; Velazco and Gardner 2009), as well as from records reported in the scientific literature. Occurrence localities from specimen tag data were then thoroughly georeferenced (i. e., for those lacking field GPS readings; Sánchez-Cordero and Guevara 2016). To reduce issues associated with spatial sampling biases (Merow et al. 2013; Boria et al. 2014), we spatially thinned our original dataset consisting of 38 localities using the spThin package in R (Aiello-Lammens et al. 2015).

Nineteen variables were retrieved as predictors to model the potential environmental niche of $P$. ismaeli based on the current presence dataset in 15 different localities (Velazco and Gardner 2009; Table 1), plus other available records. In particular, 19 bioclimatic layers (Table 3 ) and one topographic variable (elevation) were obtained from the WorldClim version 2 database (WorldClim: Global Climate Data 2017; Hijmans et al. 2005) at a spatial resolution of 30 arc-second (ca. $1 \times 1 \mathrm{~km})$. Elevation, slope, and aspect data were extracted using ArcGIS 10.4.1. The overall environmental variables are summarized in Table 3 . In order to eliminate multicollinearity and select the most fitting predictors that show more contribution power to the model, Variance Inflation Factors (VIFs) of 22 environmental 
Table 1. Records of Platyrrhinus ismaeli in Colombia used for modeling the potential distribution of the species. Life zones: A) low montane humid forest, B) low montane very humid forest, and C) premontane very humid forest. Regions: Central Range (CR), Eastern Range (ER), and Western Range (WR); Vereda (Ver); Life zone (LZ).

\begin{tabular}{|c|c|c|c|c|c|c|c|}
\hline Voucher & Latitude & Longitude & Elev. & Municipality & Department & Region & LZ \\
\hline ICN 16503 & 5.5882 & -75.9294 & 2,010 & Andes,Ver. La Soledad & Antioquia & $C R$ & A \\
\hline ICN 17165 & 6.1654 & -74.3173 & 1,860 & Santa María, Ver. Caño Negro & Boyacá & ER & $\mathrm{C}$ \\
\hline ICN 15066 & 4.9667 & -73.3440 & 1,269 & Santa María, Margen izquierda río Batá & Boyacá & ER & $C$ \\
\hline ICN 16352 & 4.9443 & -73.3252 & 1,259 & Santa María, Sitio Represa Chivor. & Boyacá & ER & c \\
\hline ICN 5441 & 5.3066 & -72.7138 & 1,970 & Pajarito, Hacienda Camijoque. & Boyacá & ER & $c$ \\
\hline ICN 19320 & 5.4166 & -71.2750 & 1,085 & Trinidad, Banco de la Cañada & Casanare & ER & $C$ \\
\hline MHNUC 1467, 1501; USNM 483575 & 2.4010 & -76.1306 & 2,638 & Moscopas, 1 Mi N Moscopas & Cauca & $C R$ & A \\
\hline ICN 8467, 8468 & 2.5518 & -76.0912 & 2,253 & Inza, Ver. Tierras Blancas, Km. 78 carril Popayan & Cauca & $\mathrm{CR}$ & A \\
\hline CMCH 1136 & 5.8982 & -76.1487 & 2,950 & El Carmen de Atrato & Chocó & WR & A \\
\hline ICN 5293, 5295 & 4.6830 & -74.3894 & 1,870 & Tena, Laguna de Pedro Pablo & Cundinamarca & ER & $\mathrm{C}$ \\
\hline $\begin{array}{l}\text { FMNH 58732, 58733, 58734, 58735, } \\
58736,58737,58738 .\end{array}$ & 2.0178 & -75.7459 & 1,100 & Parque Natural Nacional "Cueva de los Guacharos" & Huila & $C R$ & c \\
\hline $\begin{array}{l}\text { IAvH-M 1930, 1932, 1934, } \\
\text { 1990,1992, 1994, } 1996 .\end{array}$ & 1.6000 & -76.1301 & 2,800 & $\begin{array}{l}\text { Parque Natural Nacional "Cueva de los Guacharos". Puente } \\
\text { superior en Río Suaza }\end{array}$ & Huila & $C R$ & A \\
\hline ICN 13087 & 11.1430 & -73.8282 & 1,050 & $\begin{array}{l}\text { Sierra Nevada de Santa Marta, Alto de Mira, } 3 \text { Km W Río } \\
\text { Buritaca. }\end{array}$ & Magdalena & & c \\
\hline ICN 14372 & 4.2749 & -73.5874 & 1,090 & Restrepo, Salinas de Upin & Meta & ER & C \\
\hline ICN 14800 & 3.8262 & -73.8435 & 1,000 & Cubarral, Ver. Aguas Claras & Meta & ER & C \\
\hline Jiménez Ortega & 1.6812 & -78.1417 & 1,004 & Barbacoas & Nariño & WR & C \\
\hline IAvH-M 6681, 6682 & 7.2584 & -72.2259 & 1,608 & Toledo, Ver. San Isidro & Norte de Santander & ER & c \\
\hline ICN 21022 & 1.1336 & -76.6328 & 2,000 & Mocoa, El Mirador & Putumayo & $C R$ & A \\
\hline IAvH-M 6818, 6823 & 1.0715 & -76.7353 & 1,922 & Mocoa, El Mirador & Putumayo & $C R$ & C \\
\hline ICN 12476 & 4.6706 & -75.6179 & 1,975 & Finlandia, Ver. El Roble & Quindío & $C R$ & C \\
\hline ICN 12448 & 4.6834 & -75.5244 & 2,634 & $\begin{array}{l}\text { Salento, Reserva Natural Cañon Quindio, } \\
\text { frente de reforestación Monte Loro }\end{array}$ & Quindío & $C R$ & A \\
\hline UV 12694 & 4.7299 & -75.5766 & 2,250 & Quimbaya, Ver. La Suiza & Risaralda & ER & A \\
\hline ICN 8150, 8972, 8973 & 6.0967 & -73.2036 & 1,790 & Charalá, Margen derecho del Río Guillermo & Santander & ER & c \\
\hline ICN $17585,17586,17587$ & 6.4535 & -72.8266 & 2,013 & Encino, Vereda Río Negro, Las Tapias, finca El Aserradero. & Santander & ER & A \\
\hline ICN 16660, 16661 & 7.1333 & -72.9941 & 2,150 & Tona, Ver. Guarumales, finca El Pajal. & Santander & ER & A \\
\hline ICN 12448 & 7.1334 & -72.9832 & 1,800 & Tona, Sitio El Mortiño, carretera Bucaramanga-Cúcuta Km 18. & Santander & ER & C \\
\hline CZUT-M 58. & 4.4258 & -75.3697 & 1,557 & Cajamarca, Ver. Peñaranda parte Baja & Tolima & $C R$ & C \\
\hline CZUT-M 83, 84, 144, 145. & 4.4830 & -75.4532 & 2,055 & Cajamarca, Ver. Planadas & Tolima & $C R$ & A \\
\hline CZUT-M 208, 317. & 4.3865 & -75.3417 & 2,084 & Cajamarca, Ver. El salitre & Tolima & $C R$ & A \\
\hline CZUT-M 57. & 4.5440 & -75.4204 & 2,398 & Ibagué, Ver. Toche & Tolima & CR & B \\
\hline CZUT-M 206, 207 & 4.5000 & -75.3000 & 1,777 & Ibagué, Quebrada La Plata & Tolima & $C R$ & C \\
\hline $\begin{array}{l}\text { UV } 12402,12403,12405,12407 \\
13022,13023 .\end{array}$ & 3.8920 & -76.2800 & 1,124 & Buga, Ver. El Janeiro & Valle del Cauca & WR & $\mathrm{C}$ \\
\hline
\end{tabular}

variables were tested. VIFs are based on correlation coefficients $\left(R^{2}\right)$ estimated from regressions for all predictors, implemented through the'sdm' package in R (version 3.1.1). As a result, 14 variables with VIFs $>5$ were excluded (Chatterjee and Hadi 2006) and only eight variables were kept to establish the distribution model of $P$. ismaeli under the current conditions (Table 4).

MaxEnt model. In our study, the model was run using the MaxEnt algorithm (version 3.4.1 k; Guisan and Thuiller 2005; Jarvis et al. 2005; Phillips et al. 2006) with default settings. We analyzed the presence of the species in the different geographic regions, and the distribution along the Colombian Andes (Table 2) as proposed by Morrone (2014). We employed 10 replicates and the average of probability maps for habitat suitability (Hoveka et al. 2016). The train- ing and test data points were $80 \%$ and $20 \%$, respectively. The relative importance of each environmental predictor for the models of $P$. ismaeli was assessed using the percent contribution of the Jackknife test (Phillips et al. 2006), which is the best index for small sample sizes (Pearson et al. 2007).

To determine the accuracy of the resulting models, we computed the Area Under the Curve (AUC) of the Receiver Operating characteristic Curve (ROC). AUC is the dominant tool to measure model performance, mainly due to its independence from threshold choices (Bosso et al. 2013; Fois et al. 2018; Yi et al. 2016). Higher AUC values (closer to 1) indicate better model performance (Fielding and Bell 1997; Phillips et al. 2006). The AUC graph was obtained by plotting true positive predictions (sensitivity) versus false positive predictions (1-specificity; Fielding and Bell 1997). 
In addition, the minimum difference between training and testing AUC data ( $A \cup C_{\text {Diff }}$ ) was also considered; a smaller difference indicates lesser overfitting in the model (Fois et al. 2018; Warren and Seifert 2011).

The logistic output of MaxEnt application is a map, indexing the environmental suitability of $P$. ismaeli with values ranging from 0 (unsuitable) to 1 (optimal). For further analysis, the MaxEnt results were imported into ArcGIS 10.4.1, and four classes of potential habitats were grouped as follows: unsuitable $(\leq 0.10)$, low potential $(0.11-0.30)$, moderate potential $(0.31-0.70)$, and high potential $(\geq 0.71$; Yang et al. 2013; Choudhury et al. 2016; Qin et al. 2017).

\section{Results}

The re-examination of the 10 specimens reported by Bejarano-Bonilla et al. (2007; CZUT-M 206 to 208, 0317) and Galindo-Espinosa et al. (2010; CZUT-M 57, 58, 83, 84, 144, 145), as $P$. aurarius or Ch. salvini, revealed the presence of $P$. ismaeli on the foothills of the eastern slope of the central Andes of Colombia, reported herein for the first time. These records expand the known distribution of $P$. ismaeli to approximately $328 \mathrm{~km}$ southeast of the nearest known locality in the Department of Huila, in the Parque Nacional Nevado del Huila, "Cueva de los Guacharos" on the Acevedo trail (FMNH 58732, 58736,58733 to $58735,58737,58738$, Figure 1).

These new localities correspond to low montane forest and low montane wet forest, located in the Andean mountains, bordered by the dry tropical valleys of the Magdalena River. These landscapes are characterized by slopes with trees measuring approximately $12 \mathrm{~m}$ high and vegetation that includes plant species such as Pseudobomba septenatum, Calophyllum lucidum, Maclura tinctoria, Poulsenia armata, and Virola sebifera. These life zones are located primarily in areas subjected to intense agricultural and urban development, where the original forest has been cleared and replaced by plantations of coffee, fruit trees, vegetables, and other monocultures.

The diagnostic characters of the $P$. ismaeli specimens collected match the original description of the species (Velazco 2005; Diaz et al. 2016). The key features to recognize our specimens were: dorsal and ventral hairs with three bands; dense long hairs on the edge of the uropatagium; a medium forearm, less than $55 \mathrm{~mm}$; upper central incisors with one or two cusps, but not cylindrical; presence of nasals; lingual cingulum not continuous from paracone to metacone (sulcus not continuous between paracone and metacone) of M1 (Figure 2); and cranial measurements (Table 2).

Potential habitat suitability of $P$. ismaeli over current conditions. Our models showed high levels of predictive performances with values of AUC (training, $0.974 \pm 0.001$; test, $0.957 \pm 0.009)$ and $A U C_{\text {Diff }}(0.010 \pm 0.007)$ indicating a good performance with low levels of errors and correctly identifying all the localities where the species has been reported (Figure 1). The results of the contribution of variables using the Jackknife test in distribution modeling of $P$. ismaeli are
Figure 1. Map for potential current habitat suitability for Platyrrhinus ismaeli in Colombia from records in the various Colombian collections. Habitat suitability classes include: unsuitable, low potential, moderate potential, and high potential.

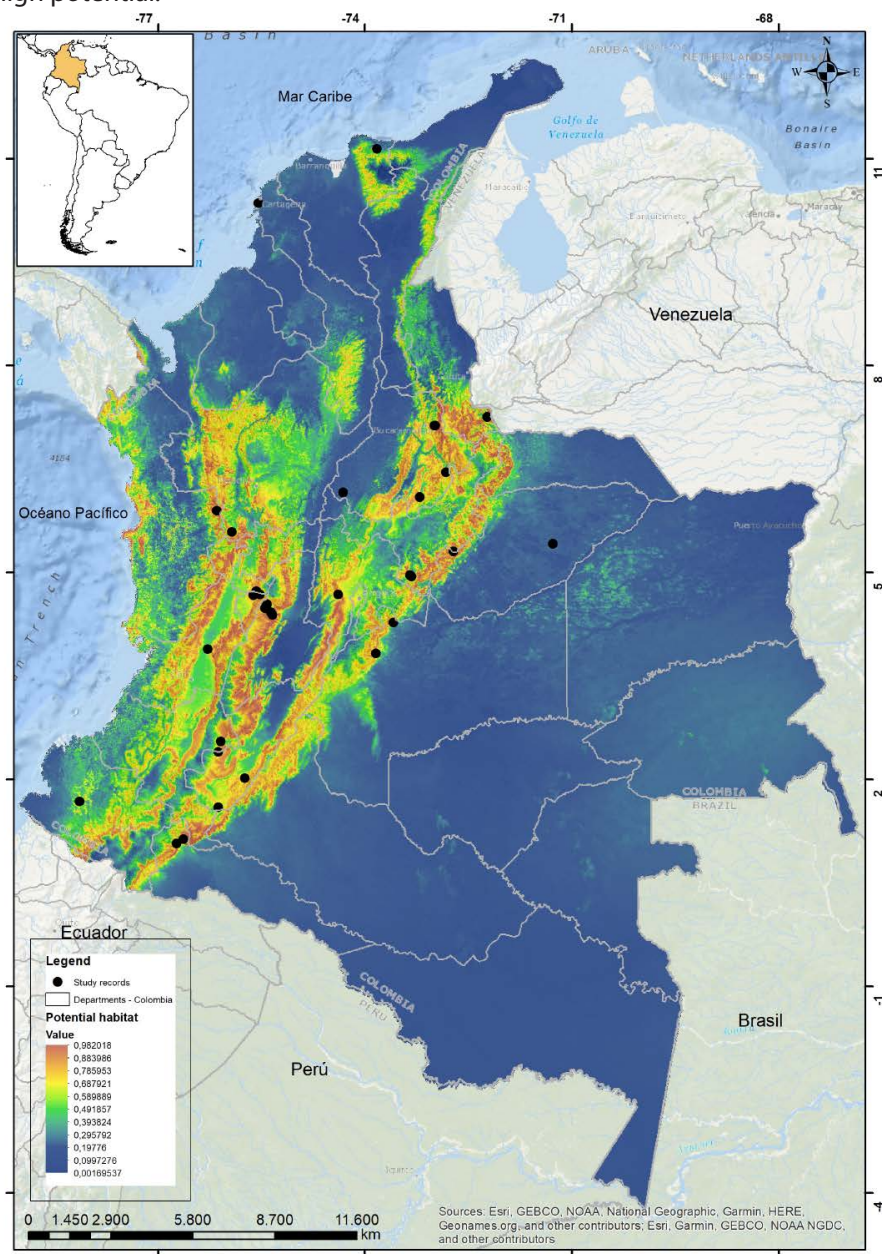

showed in Table 2. Environmental predictors that exhibited the highest mean contributions are annual precipitation (Bio12), annual mean temperature (Bio1), and elevation (Elev). At the same time, Bio1, Bio12, Bio9, Elev, and Bio5 provided high gains $(>2)$ to the model when used individually, indicating that each of these variables separately contribute the most useful information than the rest of variables. Considering the permutation importance, Bio1, Bio12, and Elev were the main environmental variables that have influenced the potential distribution of $P$. ismaeli (Table 2). The model predicts a continuous distribution range in the Colombian Andean region, spreading across the three cordilleras, i. e., western, central, and eastern, from the south in Nudo de los Pastos up to the Catatumbo subregion in the Department of Norte de Santander, including the Choco-Magdalena, Orinoquia, and North-Andean biogeographic provinces.

The response curves of eight variables related to $P$. ismaeli habitat suitability are shown in Figure 3. While considering temperature probabilities, the mean annual temperature range (Bio1) of $P$. ismaeli was 12.0 to $25.5^{\circ} \mathrm{C}$, whereas the mean diurnal temperature (Bio2) ranged from 16.5 to $20.15^{\circ} \mathrm{C}$. In addition, the range of isothermality (Bio3) varied from 43.1 to 46.3 , whereas the mean temperature of the driest quarter (Bio9) varied from 28.0 to $32.0^{\circ} \mathrm{C}$. On 
Table 2. Selection of external and cranial measurements of $P$. ismaeli specimens collected in the central Andes eastern slope, Colombia. The measurements of the holotype and paratype of $P$. ismaeli were taken from Velazco (2005).

\begin{tabular}{|c|c|c|c|c|c|}
\hline \multirow{2}{*}{$\begin{array}{c}\text { Characteristics } \\
\text { Sex }\end{array}$} & \multicolumn{2}{|c|}{$\begin{array}{c}\text { This study } \\
\text { CZUT-M } \\
0058,0084\end{array}$} & \multirow{2}{*}{$\begin{array}{c}\begin{array}{c}\text { Holotype } \\
\text { MUSM } \\
4946\end{array} \\
\text { Male }\end{array}$} & \multicolumn{2}{|c|}{$\begin{array}{c}\text { Paratypes } \\
\text { FMNH } 129134, \\
129136\end{array}$} \\
\hline & Male & Female & & Female & Male \\
\hline Weight & 32.00 & 39.00 & 35.00 & 40.00 & 38.00 \\
\hline Total length & 88.32 & 80.40 & 84.00 & 82.00 & 87.00 \\
\hline Hind foot length & 17.89 & 13.35 & 18.00 & 13.00 & 18.00 \\
\hline Ear length & 22.75 & 21.03 & 10.00 & 21.00 & 22.00 \\
\hline Forearm length & 52.65 & 53.25 & 52.00 & 53.00 & 54.00 \\
\hline Tibia length & 21.35 & 19.75 & 21.68 & 19.52 & 21.68 \\
\hline Greatest length of skull & 28.20 & 27.08 & 27.94 & 27.77 & 28.15 \\
\hline Condyloincisive length & 27.30 & 26.59 & 27.10 & 26.57 & 27.47 \\
\hline Condylocanine length & 26.92 & 26.07 & 26.22 & 26.07 & 26.88 \\
\hline Postorbital breadth & 6.40 & 6.15 & 6.54 & 6.27 & 6.57 \\
\hline Zygomatic breadth & 17.90 & 16.8 & 17.13 & 16.93 & 18.21 \\
\hline Braincase breadth & 12.18 & 11.5 & 12.00 & 11.57 & 12.29 \\
\hline Mastoid breadth & 13.69 & 12.5 & 13.99 & 13.63 & 14.72 \\
\hline Maxillaty tooth row length & 11.78 & 11.05 & 11.35 & 11.43 & 11.66 \\
\hline Breadth across maxilla & 20.71 & 20.56 & 12.63 & 12.65 & 23.81 \\
\hline Palatal length & 15.94 & 14.9 & - & - & - \\
\hline Molariform teeth row length & 12.04 & 11.14 & - & - & - \\
\hline Width across first upper molars & 13.67 & 21.67 & - & - & - \\
\hline $\begin{array}{l}\text { Width across second upper } \\
\text { molars }\end{array}$ & 13.89 & 21.97 & - & - & - \\
\hline Dentary length & 24.60 & 28.00 & - & - & - \\
\hline Length of mandible toothrow & 15.70 & 21.56 & - & - & - \\
\hline Coranoid height & 7.07 & 14.96 & - & - & - \\
\hline Width at mandible condyles & 8.36 & 15.59 & - & - & _- \\
\hline Breadth across molars & 15.42 & 22.83 & _ & _ & - \\
\hline
\end{tabular}

the other hand, the range of annual precipitation (Bio12) was 1,000 to $4,000 \mathrm{~mm}$ per year while the suitable habitat occurs under a precipitation seasonality of 1,400 to 4,000 , with a peak at $1,658 \mathrm{~mm}$.

Furthermore, there is a positive relationship between habitat suitability for $P$. ismaeli and precipitation of the driest month. The elevation range suitable for $P$. ismaeli was 1,200 to 2,850 masl, with an optimal elevation at around 2,500 masl. Indeed, the conditions of highest suitability for P. ismaeli were an annual temperature of $21^{\circ} \mathrm{C}$, annual precipitation of $4,000 \mathrm{~mm}$, and an elevation of 2,500 masl. By contrast, areas with an elevation above 3,000 masl or below 1,200 masl, and with an annual temperature above $30^{\circ} \mathrm{C}$ were the least suitable for $P$. ismaeli.

The potential distribution map of $P$. ismaeli in Colombia is shown in Figure 3. Out of the total area of 1,141,748 km², some $5,103 \mathrm{~km}^{2}$ were potentially suitable for $P$. ismaeli. This area was divided into $1,793 \mathrm{~km}^{2}$ with a low potential, 1,758 $\mathrm{km}^{2}$ with a moderate potential, and only $1,551 \mathrm{~km}^{2}$ with a high probability of suitable ecological conditions. The majority of suitable habitats $(\geq 0.71)$ were located in areas located in the mid-north of Colombia.

\section{Discussion}

Our results update and show a wider distribution range of $P$. ismaeli in Colombia (Table 1). This work is the first record of this species in the eastern slope of central range of Colombia. The existing records of the species correspond to the life zones low montane forest, low montane wet forest and premontane very humid forest. These life zones in Colombia are subjected to an increasing destruction and degradation of habitats, primarily due to agriculture, forestry, illegal crops, and mining, which altogether have resulted in a decline of more than $30 \%$ of the populations of $P$. ismaeli (Ramírez-Chaves and Suárez-Castro 2014; Solari 2016); thus, the species is currently listed as Near Threatened (NT).

The records reported here also represent an extension of the ecological range of $P$. ismaeli. The life zone represented by low montane very humid forest has environmental and climatic characteristics that differ from others previously reported for the species, with precipitation between 2,000 to $4,000 \mathrm{~mm}$ and temperature between 12 to $18^{\circ} \mathrm{C}$. Natural forests in this area were characterized by broad extensions, several arboreal strata, many epiphytes, and fertile soils; however, today most of the forest has been transformed into pastures for agriculture and cattle raising, which causes overgrazing and excessive clearing (Guzmán-González 1996).

Our results show that under the current climatic conditions, the areas with the best environmental suitability for $P$. ismaeli are located in the north-center regions of Colombia. This finding is consistent with the records in Colom-

Figure 2. a) Dorsal, ventral, and occlusal views of the skull and jaw of a male of Platyrrhinus ismaeli (CZUT-M 317) captured in El Salitre trail, municipality of Cajamarca, Department of Tolima, Colombia, in July 2003. b) Occlusal views of the left first upper molar (M1) and second upper molar (M2). Lingual cingulum not continuous from paracone to metacone of first upper molar.

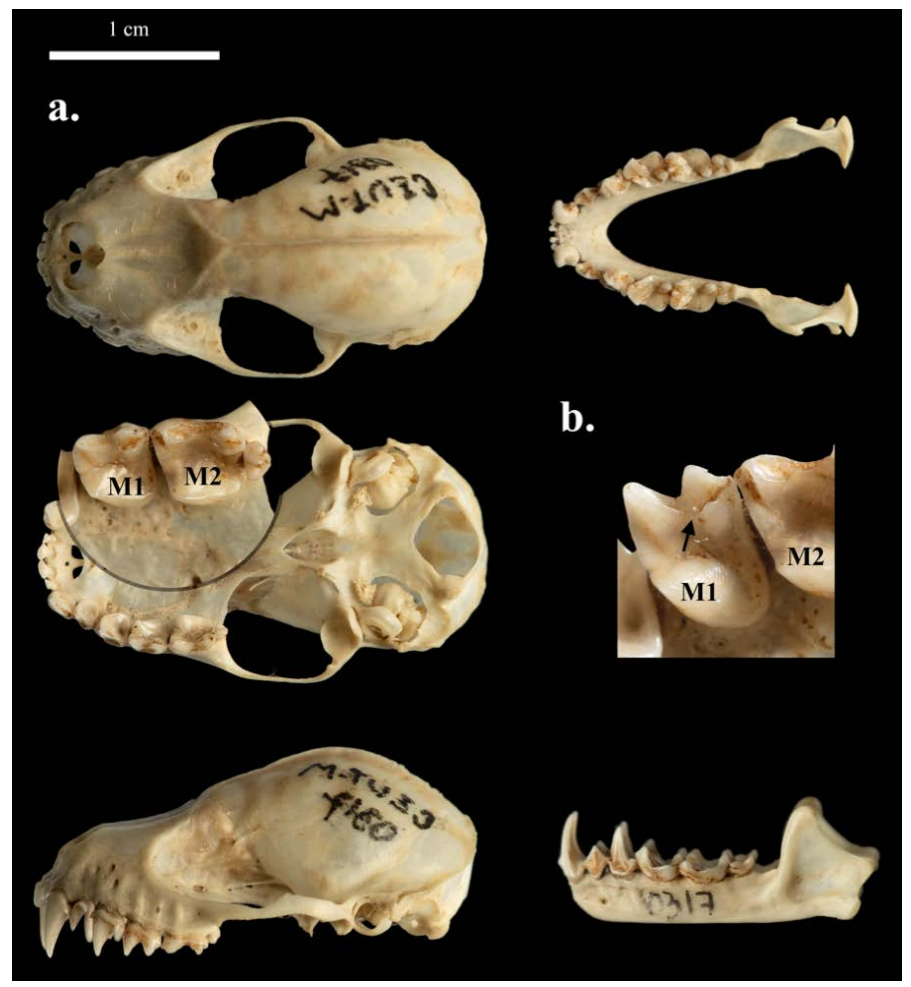


bian collections and the known distribution reported in the literature (Solari et al. 2013), and suggests that the current distribution represents the optimum climatic conditions for the species, in sites of high altitude (2,500 masl) and near steep slopes, with riparian vegetation ecosystems.

The results of the model show that all the current and predicted sites fulfill suitable conditions for $P$. ismaeli, i. e., high elevation (1,200 to 2,850 masl), low temperature ( 12.0 to $25.5^{\circ} \mathrm{C}$ ), and annual precipitation range of 1,000 to 4,000 $\mathrm{mm}$. Consequently, warm sites with elevation $<1,200$ masl are less suitable for the species. These results are in line with those from Solari et al. (2013), which report that $P$. ismaeli mainly lives in wet habitats with a narrow elevation range from 1,230 to 2,950 masl.

However, some studies also report the presence of $P$. ismaeli in premontane forests in mountain ranges (AsprillaAguilar et al. 2016). In fact, this species prefers secondary forests with abundant vegetation cover, rather than pastures and monocultures or moderately fragmented areas (Tirira 2011), to the extent that it is considered endemic to Yungas in Perú, the ecoregion with the largest number of endemic species (Pacheco et al. 2009). The distribution of $P$. ismaeli covers the driest forests of the western slopes of the Andes in northern Perú (Rengifo et al. 2011).

Table 3. Environmental variables used for modeling the potential distribution of $P$. ismaeli. Issues related to collinearity were avoided by removing variables with variance inflation factor (VIF) values $>5$. Variables highlighted in bold were selected through a multi-collinearity test and were used in modeling. All the variables were obain from the WorldClim.

\begin{tabular}{|c|c|c|}
\hline Variable & Code/Unit & VIF \\
\hline Mean Annual Temperature & Bio1 $\left({ }^{\circ} \mathrm{C}\right)$ & 1.74 \\
\hline $\begin{array}{l}\text { Mean Diurnal Range (Mean of monthly } \\
\text { (max temp - min temp) }\end{array}$ & $\mathrm{Bio} 2\left({ }^{\circ} \mathrm{C}\right)$ & 2.68 \\
\hline Isothermality (BIO2/BIO7) (* 100) & Bio3 & 1.10 \\
\hline $\begin{array}{l}\text { Temperature Seasonality } \\
(\text { Standard deviation } * 100)\end{array}$ & $\mathrm{Bio} 4\left({ }^{\circ} \mathrm{C}\right)$ & 8.53 \\
\hline Max. Temp. Warmest Month & $\mathrm{Bio5}\left({ }^{\circ} \mathrm{C}\right)$ & 12.90 \\
\hline Min. Temp. Coldest Month & Bio6 $\left({ }^{\circ} \mathrm{C}\right)$ & 14.20 \\
\hline Temperature Annual Range (BIO5-BIO6) & $\mathrm{Bio7}\left({ }^{\circ} \mathrm{C}\right)$ & 13.40 \\
\hline Mean Temp. of the Wettest Quarter & $\mathrm{Bio} 8\left({ }^{\circ} \mathrm{C}\right)$ & 9.20 \\
\hline Mean Temp. of the Driest Quarter & Bio9 $\left({ }^{\circ} \mathrm{C}\right)$ & 3.14 \\
\hline Mean Temp. of the Warmest Quarter & Bio10 $\left({ }^{\circ} \mathrm{C}\right)$ & 9.15 \\
\hline Mean Temp. of the Coldest Quarter & Bio11 $\left({ }^{\circ} \mathrm{C}\right)$ & 9.23 \\
\hline Annual Precipitation & Bio12 (mm) & 2.51 \\
\hline Precipitation of the Wettest Month & Bio13 (mm) & 8.93 \\
\hline Precipitation of the Driest Month & Bio14 (mm) & 3.39 \\
\hline $\begin{array}{l}\text { Precipitation Seasonality } \\
\text { (Coefficient of Variation) }\end{array}$ & Bio15 & 1.85 \\
\hline Precipitation of the Wettest Quarter & Bio16 (mm) & 12.86 \\
\hline Precipitation of the Driest Quarter & Bio17 (mm) & 6.60 \\
\hline Precipitation of the Warmest Quarter & Bio18 (mm) & 9.90 \\
\hline Precipitation of the Coldest Quarter & Bio19 (mm) & 12.30 \\
\hline Elevation & Elev $(m)$ & 3.65 \\
\hline
\end{tabular}

Table 4. Estimates of average contribution and permutation importance of the environmental variables used in the MaxEnt modeling for $P$. ismaeli.

\begin{tabular}{lrr}
\hline \multicolumn{1}{c}{ Variable } & Percent contribution & Permutation importance \\
\hline Bio1 & 13.6 & 29.5 \\
Bio2 & 0.6 & 2.3 \\
Bio3 & 3.6 & 7.4 \\
Bio9 & 1.5 & 3.6 \\
Bio12 & 33.6 & 8.0 \\
Bio14 & 1.5 & 1.4 \\
Bio15 & 0.3 & 1.1 \\
Elev & 12.5 & 5.3 \\
\hline
\end{tabular}

Our analysis revealed that the highest probability of occurrence of $P$. ismaeli is recorded in the center of the North Andean Province in the Departments of Antioquia, Caldas, Cundinamarca, Huila, Tolima, Quindío, and Valle del Cauca. The model also predicts a high probability of occurrence in the Choco--Magdalena region and the east of the Orinoquia region. Altogether, this suggests that the distribution of $P$. ismaeli is governed by the ecological association between the Chocó biogeographic region and the valleys of the Magdalena and Cauca rivers, an exchange zone of the biological elements of these areas with those of the cis-Andean and Magdalena valleys, moving through the foothills of the Orinoquia, the Burbua depression, and the Catatumbo basin. This pattern has

Figure 3. Response curves of eight environmental predictors used in the ecological niche model for $P$. ismaeli. For abbreviations, see Table 3 .
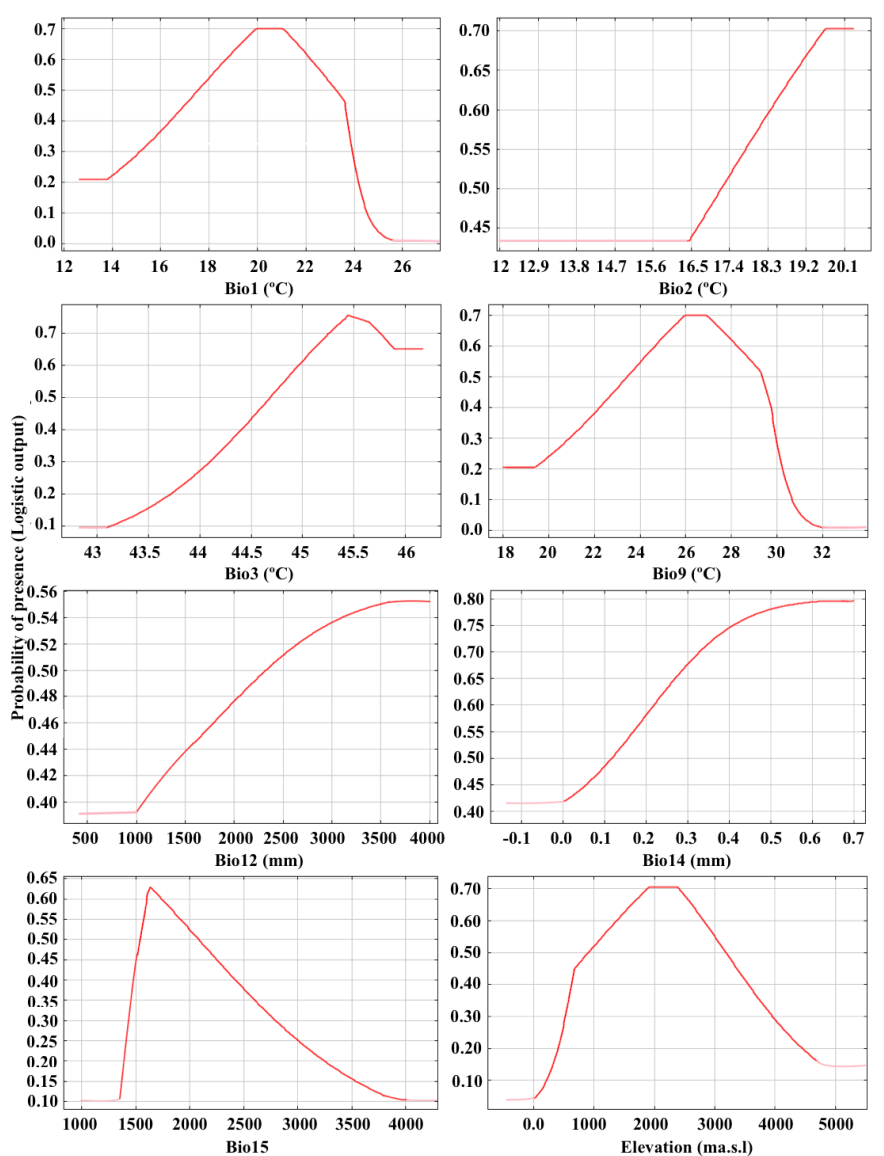
been documented for different groups of animals, including bats (Hernández-Camacho et al. 1992; Mantilla-Meluk et al. 2009; García- Herrera et al. 2018).

In addition, MaxEnt outputs under the current conditions indicate that the distribution range of $P$. ismaeli is influenced primarily by annual temperature, annual precipitation, and elevation. This is consistent with factors affecting the suitable habitats of several groups of vertebrates such as amphibians, non-volant mammals, bats, and birds (Moura et al. 2016), where climatic factors and elevation resulted core drivers of the distribution of vertebrate species (Ferro Muñoz et al. 2018).

This study provides ecological information about the habitats occupied by this species, as well as a detailed geographic distribution in the Andean region. This information can be used to support the development of scientifically sound conservation plans, as well as detailed and reliable distribution maps for Colombia, thus allowing the identification of areas that are suitable for the conservation of this species in the country. However, further studies are required addressing the distribution of species in the Central range of Colombia, a region that maintains some high-biodiversity areas in spite of the recent anthropogenic impacts.

\section{Acknowledgments}

We thank the Grupo de Investigación en Zoología and the office of scientific research at Universidad del Tolima (Convocatoria 004-2017) for logistical and economic support and to the convocatoria para la formación de capital humano de alto nivel para el Departamento del Tolima, No. 755 de 2016, Colciencias, at which time the first two authors reviewed the specimens and drafted this manuscript. We thank the researchers who collected the reported species (D. Bejarano Bonilla, M. Bernal Bautista, E. Galindo, K. Gutierrez and J. Peña), and the various institutions that gave us information from their collections (ICN, IAvH-M, UV, and $\mathrm{NMNH}$ ), especially to the Instituto de Ciencias Naturales at Universidad Nacional de Colombia for the information provided. We also thank $\mathrm{H}$. Cruz for his technical support in the creation of the map, and especially M. E. Sánchez-Salazar, S. Solari and H. Tamayo for the English translation and for their suggestions for improving the manuscript. We thank the two external referees for providing us with useful comments that improved this work.

\section{Literature cited}

Aiello-Lammens, M. E., R. A. Boria, A. Radosavljevic, B. Vilela, and R. P. Anderson. 2015. spThin: An R package for spatial thinning of species occurrence records for use in ecological niche models. Ecography 38:541-545.

Altringham, J. 2011. Bat: From evolution to conservation. Oxford press. New York, U.S.A..

Asprilla-Aguilar, A. A., A. M. Jiménez-Ortega, and H. MantillaMeluk. 2016. Murciélagos (Chiroptera) del departamento del Chocó, occidente colombiano. Revista Biodiversidad Neotropical 6:188-211.
Bejarano-Bonilla, D. A., Y. Yate-Rivas, and M. H. Bernal-Bautista. 2007. Diversidad y distribución de la fauna Quiróptera en un transecto altitudinal en el departamento del Tolima, Colombia. Caldasia 29: 297-308.

Boria, R. A., L. E. Olson, S. M. Goodman, and R. P. Anderson. 2014. Spatial filtering to reduce sampling bias can improve the performance of ecological niche models. Ecological Modelling 275:73-77.

Bosso ,L., Di. M. Febbraro, G. Cristinzio, A. Zoina, And D. Russo. 2016. Shedding light on the effects of climate change on the potential distribution of Xylella fastidiosa in the Mediterranean basin. Biological Invasions 18:1759-1768.

Bracamonte, C. 2011. El rol de los murciélagos en el mantenimiento de los bosques. Temas de Biología y Geología del NOA 1:52-57.

Castro-Luna, A. A., And J. Galindo-González. 2012. Seed dispersal by phyllostomid bats in two contrasting vegetation types in a Mesoamerican reserve. Acta Chiropterologica 14:133-142.

Chatterjee, S. And A. S. Hadi. 2006. Simple linear regression. Pp. 21-51 in Regression Analysis by example (Shewhart, W. A., and S. S. Wilks, eds.). John Wiley and Sons, Hoboken. Cairo. Egypt.

Choudhury, M. R., P. Deb, H. Singha, B. Chakdar, and M. Medhi. 2016. Predicting the probable distribution and threat of invasive Mimosa diplotricha Suavalle and Mikania micrantha Kunth in a protected tropical grassland. Ecological Engineering 97:23-31.

Cirranello, A. L., N. B. Simmons, S. Solari, And R. J. Baker. 2016. Morphological diagnoses of higher-level phyllostomid taxa (Chiroptera: Phyllostomidae). Acta Chiropterologica 18:39-71.

Díaz, M. M., S. Solari, L. F. Aguirre, L. M. S. Aguiar, and R. M. Barquez. 2016. Clave de identificación de los murciélagos de Sudamérica. Publicación especial №2, PCMA (Programa de Conservación de los Murciélagos de Argentina). Tucumán. Argentina.

Estrada-Villegas, S., J. Pérez-Torres, and P. R. Stevenson. 2010. Ensamblaje de murciélagos en un bosque subandino colombiano y análisis sobre la dieta de algunas especies. Mastozoología Neotropical 17:31-41.

Ferro Muñoz, N., A. Giraldo, and O. E. Murillo García. 2018. Composition, trophic structure and activity patterns of the understory bats of the Bitaco Forest Reserve. Acta Biológica Colombiana 23:170-178.

Fielding, A. H., AND J. F. Bell. 1997. A review of methods for the assessment of prediction errors in conservation presence/ absence models. Environmental Conservation. 24:38-49.

Fois, M., A. Cuena-Lombraña, G. Fenu, and G. Bacchetta. 2018. Using species distribution models at local scale to guide the search of poorly known species: Review, methodological issues and future directions. Ecological Modelling 385:124-132.

Galindo-Espinosa, E. Y., K. A. Gutiérrez-Díaz, and G. ReinosoFlórez. 2010. Lista de los quirópteros del departamento del Tolima, Colombia. Biota Colombiana 11:107-116.

Galindo-González, J., S. Guevara, And V. J. Sosa. 2000. Bird- and bat-generated seed rains at isolated trees in pastures in a tropical rainforest. Conservation Biology 14:1693-1703.

García-Herrera L. V., L. A. Ramírez-Fráncel, and G. Reinso-Flórez. 2018. Potential distribution of Sphaeronycteris toxophyllum in Colombia and new record. Therya 9:255-260. 
García-Herrera L. V., L. A. Ramírez-Fráncel, and G. ReinosoFlórez. 2019. Consumo de plantas pioneras por murciélagos frugívoros en un fragmento de bosque seco tropical (Colombia). Ciencia en desarrollo 10. En prensa.

Gardner A. L. 2008. Genus Platyrrhinus Saussure, 1860. Pp. 329-342 in Mammals of South America, Volume 1: Marsupials, Xenarthrans, Shrews, and Bats (Gardner, A. L. ed.). University of Chicago Press. Chicago, U.S.A.

Guisan A., AND W. Thuiller. 2005. Predicting species distribution: offering more than simple habitat models. Ecology Letters 8:993-1009.

Guzmán-González, D. A. 1996. Zonas de vida o formaciones vegetales Área Jurisdicional C.A.R. Santafé de Bogotá, Colombia. Hernández-Camacho, J., A. Hurtado-Guerra, R. Ortiz-Quijano, and T. Walschnurguer. 1992. Unidades Biogeográficas de Colombia. Pp. 105-152 in La diversidad biológica de Iberoamérica (G Haler, ed.). Acta Zoológica Mexicana, vol. especial 1992. Instituto de Ecología, A. C. Xalapa, México.

Hijmans, R. J., S. E. Cameron, J. L. Parra, P. G. Jones, and A. Jarvis. 2005. Very high re-solution interpolated climate surfaces for global land areas. International Journal of Climatology 25:1965-1978.

Holdridge, L. 1987. Ecología basada en zonas de vida. Instituto Interamericano de Ciencias Agrícolas, San José de Costa Rica. Costa Rica.

Hoofer, S. R., S. Solari, P. A. Larsen, R. D. Bradley, and R. J. Baker. 2008. Phylogenetics of the fruit-eating bats (Phyllostomidae: Artibeina) inferred from mitochondrial DNA sequences. Occasional Papers of the Museum, Texas Tech University 277:1-16.

Hoveka, L. N., B. S. Bezeng, K. Yessoufou, J. S. Boatwright, and M. Van Der Bank. 2016. Effects of climate change on the future distributions of the top five freshwater invasive plants in South Africa. South African Journal of Botany 102:33-38.

Instituto de Ciencias Naturales, Facultad de Ciencias, Universidad Nacional de Colombia. 2019. Colecciones en Línea. http:// www.biovirtual.unal.edu.co. Accessed on March 12, 2019.

IUCN. 2019. International Union for Conservation of Nature. $\quad$ http://dx.doi.org/10.2305/IUCN.UK.2008.RLTS. T20599A9213038. Accessed on July 23, 2019.

Jarvis, A., K. Williams, D. Williams, L. Guarino, P. J. Caballero, AND G. Mottram. 2005. Use of GIS for optimizing a collecting mission for a rare wild pepper (Capsicum exuosum Sendtn) in Paraguay. Genetic Resources and Crop Evolution 2:671-682.

Jimenez-Ortega, A. M. 2013. Conocimiento y conservación de los murciélagos filostómidos (Chiroptera: Phyllostomidae) y su utilidad como bioindicadores de la perturbación de los bosques neotropicales. (tesis PhD). Madrid: Universidad Autónoma de Madrid; España.

Mantilla-Meluk, H., A. M. Jiménez-Ortega, and R. J. Baker. 2009. Phyllostomid bats of Colombia: annotated checklist, distribution, and biogeography. Special Publications, Museum of Texas Tech University 56:1-44.

Marques, M. C., AND R. J. BaKer. 2009. Effect of bats on seed distribution and germination of Calophyllum brasiliense (Clusiaceae). Ecotropica 15:1-6.

Medellin, R. A. 2003. Diversity and conservation of bats in México: research priorities, strategies, and actions. Wildlife Society Bulletin 31: 87-97.
Medellin, R., M. Equihua, And M. Amin. 2000. Bat diversity and abundance as indicators of disturbance in Neotropical rainforests. Conservation Biology 14:1666-1675.

Merow, C., M. J. Smith, And J. A. Silander. 2013. A practical guide to MaxEnt for modeling species' distributions: What it does, and why inputs and settings matter. Ecography 36:1058-1069.

Molinari, J., X. E. Bustos, S. F. Burneo, M. A. Camacho, S. A. Moreno, and G. Fermin. 2017. A new polytypic species of yellow-shouldered bats, genus Sturnira (Mammalia: Chiroptera: Phyllostomidae), from the Andean and coastal mountain systems of Venezuela and Colombia. Zootaxa 4243:75-96.

Morrone, J. J. 2014. Biogeographical regionalization of the Neotropical region. Zootaxa 3782:1-110.

Moura, M. R., F. Villalobos, G. C. Costa, and P. C. A. García. 2016. Disentangling the Role of Climate, Topography and Vegetation in Species Richness Gradients. PloS ONE 11:1-16.

Muñoz, J. 2001. Los murciélagos de Colombia. Sistemática, distribución, historia natural y ecología. Editorial Universidad de Antioquia. Medellín, Colombia.

Naranjo, A., J. Homer, R. Jahoda, L.W. Diamond, A. Uribe, C. Perez, H. Paz, C. Mejía, and J. Weil. 2017. La Colosa Au Porphyry Deposit, Colombia: Minealization Styles, Structural Controls, and Age Constraints. Economic Gology 113:553-578.

National Museum of Natural History, Smithsonian Institution (NMNH Mammals). 2019. Colecciones en Línea. http://n2t. net/ark:/65665/300004274-7296-4790-b819-d2226ad068ea. Source: http://collections.nmnh.si.edu/ipt/resource?r=nmnh_ extant_dwc-a. Accessed on March 12, 2019.

Pacheco, V., R. Cadenillas, E. Salas, C. Tello, and H. Zeballos. 2009. Diversidad y endemismo de los mamíferos del Perú. Revista Peruana de Biología 16:5-32.

Pearson, R. G., C. J. Raxworthy, M. Nakamura, and A. T. Peterson. 2007. Predicting species distributions from small numbers of occurrence records: A test case using cryptic geckos in Madagascar. Journal of Biogeography 34:102-117.

Phillips, S. J., R. P. Anderson, And R. E. Schapire. 2006. Maximum entropy modeling of species geographic distributions. Ecological Modelling 190:231-259.

Qın, A., B. Liu, Q. Guo, R. W. Bussmann, F. MA, Z. Jian, G. Xu, AND S. Pel. 2017. Maxent modeling for predicting impacts of climate change on the potential distribution of Thuja sutchuenensis Franch., and extremely endangered conifer from southwestern China. Global Ecology and Conservation 10:139-146.

Ramírez-Chávez, H. E., A. F. Suárez-Castro, and J. F. GonzálezMaya. 2016. Cambios recientes a la lista de mamíferos de Colombia. Mammalogy Notes 3:1-20.

Ramírez-Chávez, H. E., and A. F. Suárez-Castro. 2014. Adiciones y cambios a la lista de mamíferos de Colombia: 500 especies registradas para el territorio nacional. Notas Mastozoológicas Sociedad Colombiana de Mastozoología 12:31-34.

Redondo, R. A. F., L. P. S. Brina, R. F. Silva, A. D. Ditchfield, And F. R. Santos. 2008. Molecular systematics of the genus Artibeus (Chiroptera: Phyllostomidae). Molecular Phylogenetics and Evolution 49:44-58.

Rengifo, E. M., V. Pacheco, and E. Salas. 2011. An additional record of Platyrrhinus ismaeli Velazco, 2005 on the western 
slope of Peru, with taxonomic comments. Chiroptera neotropical 17:803-807.

Sampaio, E. M., E. K. V. Kalko, E. Bernard, B. Rodríguez-Herrera, AND C. O. Handley. 2003. A biodiversity assessment of bats (Chiroptera) in a tropical lowland rainforest of Central Amazonia, including methodological and conservation considerations. Studies on Neotropical Fauna and Environment 38:17-31.

Sánchez-Cordero, V., And L. Guevara. 2016. Modelado de la distribución potencial de las musarañas (Mammalia, Soricidae). Mexico City, Mexico: Universidad Nacional Auto noma de México. Instituto de Biología. Databases SNIBCONABIO, project JM044.

SolARI, S. 2016. Platyrrhinus ismaeli. The IUCN Red List of Threatened Species 2016: e.T136232A22002129. http://dx.doi.org/10.2305/IUCN.UK.2016-2.RLTS. T136232A22002129 Accessed on July 19, 2018.

Solari, S., S. R. Hoofer, P. A. Larsen, A. D. Brown, R. J. Bull, J. A. Guerrero, J. Ortega, J. P. Carrera, R. D. Bradley, and R. J. BAKER. 2009. Operational criteria for genetically defined species: analysis of the diversification of the small fruit-eating bats, Dermanura (Phyllostomidae: Stenodermatinae). Acta Chiropterologica 11:279-288.

Solari, S., Y. Muñoz-Saba, J. V. Rodríguez-Mahecha, T. R. Defler, H. E Ramírez-Chaves, and F. Trujillo. 2013. Riqueza, endemismo y conservación de los mamíferos de Colombia. Mastozoología Neotropical 20:301-65.

TiriRA, D. G. 2011. Guía de campo de los mamíferos del Ecuador. Ediciones Murciélago Blanco, Publicación especial sobre los mamíferos del Ecuador 6. Quito, Ecuador.

Vaughan, N. 1997. The diets of British bats (Chiroptera). Mammal Review 27:77-94.

Velazco, P. M., A. L. Gardner, and B. D. Patterson. 2010. Systematics of the Platyrrhinus helleri species complex (Chiroptera: Phyllostomidae), with descriptions of two new species. Zoological Journal of the Linnean Society 159:785-812.

Velazco, P. M., ANd B. D. Patterson. 2013. Diversification of the yellow-shouldered bats, genus Sturnira (Chiroptera, Phyllostomidae), in the New World tropics. Molecular Phylogenetics and Evolution 68:683-698

Velazco, P. M., ANd B. K. Lım. 2014. A new species of broad-nosed bat Platyrrhinus Saussure, 1860 (Chiroptera: Phyllostomidae) from the Guianan Shield. Zootaxa 3796:175-193.

Velazco, P. M., And S. Solari. 2003. Taxonomía de Platyrrhinus dorsalis y Platyrrhinus lineatus (Chiroptera: phyllostomidae) en Perú. Mastozoología Neotropical 10:303-319.

Velazco, P. M. 2005. Morphological Phylogeny of the bat genus Platyrrhinus Saussure, 1860 (Chiroptera: Phyllostomidae) with the description of four new species. Fieldiana, Zoology. 105:1-54.

Velazco, P. M. Guevara, And J. Molinari. 2018. Systematics of the broad-nosed bats, Platyrrhinus umbratus (Lyon, 1902) and P. nigellus (Gardner and Carter, 1972) (Chiroptera: Phyllostomidae), based on genetic, morphometric, and ecological niche analyses. Neotropical Biodiversity 4:119-133.

Velazco, P. M., ANd A. L. Gardner. 2009. A new species of Platyrrhinus (Chiroptera: Phyllostomidae) from western Colombia and Ecuador, with emended diagnoses of $P$. aquilus, $P$. dorsalis, and $P$. umbratus. Proceedings of the Biological Society of Washington 122:249-281.
Velazco, P. M., And B. D. Patterson. 2008. Phylogenetics and biogeography of the broad-nosed bats, genus Platyrrhinus (Chiroptera: Phyllostomidae). Molecular Phylogenetics and Evolution 49:749-759.

Velazco, P. M., And B. D. Patterson. 2014. Phylogenetics and biogeography of the broad-nosed bats, genus Platyrrhinus (Chiroptera: Phyllostomidae). Molecular Phylogenetics and Evolution 49:749-759

Velazco, P. M., and B. D. Patterson. 2014. Two new species of yellow-shouldered bats, genus Sturnira Gray, 1842 (Chiroptera, Phyllostomidae) from Costa Rica, Panama and western Ecuador. ZooKeys 402:43-66.

Velazco, P. M., and B. D. Patterson. 2019. Small mammals of the Mayo River Basin in Northern Peru, With the description of a new species of sturnira (Chiroptera: Phyllostomidae). Bulletin American Museum of natural History 429:1-67.

Warren, D. L., AND S. N. Seifert. 2011. Ecological niche modeling in Maxent: The importance of model complexity and the performance of model selection criteria. Ecological Applications 21:335-342.

WorldClim: Global Climate Data. 2017. Colecciones en Línea. http://www.worldclim.org. Accessed on July 12, 2019.

YanG, X. Q., S. P. S. Kushwaha, S. Saran, J. Xu, and P. S. Roy. 2013. Maxent modeling for predicting the potential distribution of medicinal plant, Justicia adhatoda L.: in Lesser. Ecological Engineering 51:83-87.

Yı, Y. J., X. Cheng, Z. F. Yang, AND S. H. Zhang. 2016. Maxent modeling for predicting the potential distribution of endangered medicinal plant $(H$. riparia Lour) in Yunnan. China. Ecological Engineering 92:260-269.

Associated editor: Sergio Solari

Submitted: June 17, 2019; Reviewed: July 19, 2019;

Accepted: November 20, 2019; Published on line: March 26, 2020. 


\section{Appendix 1}

Specimens analyzed: For each specimen, the collection acronym and museum number are provided, and the localities are listed by country, Department, and specific locality.

Platyrrhinus ismaeli —Colombia. Antioquia: Andes, Vereda La Soledad (ICN 16503). Boyacá: Santa María, Vereda Caño Negro, camino entre las fincas Santa Rosita y El Tesoro, ruta a Palo Negro (ICN 17165). Casanare: Trinidad, Banco de la Cañada (ICN 19320). Cauca: Moscopas, 1 Mi N Moscopas (MHNUC 1467, 1501; USNM 483575). Chocó: El Carmen de Atrato (CMCH 001136). Cundinamarca: Tena, alrededor de la laguna de Pedro Pablo (ICN 5293, 5295). Huila: Parque Natural Nacional "Cueva de los Guacharos". Puente superior en Río Suaza (FMNH 58732 to 58738;IAvH-M 1930, 1932, 1934, 1990,1992, 1994, 1996). Meta: Restrepo, Salinas de Upin (ICN 14372). Cubarral, Vereda Aguas Claras, Escuela Santa Clara, finca La Reforma (ICN 14800). Nariño: Barbacoas (Jiménez Ortega). Norte de Santander: Toledo, Vereda San Isidro (IAvH-M 6681, 6682). Putumayo: Mocoa, El Mirador (ICN 21022; IAvH-M 6818, 6823). Quindio: Filandia, Vereda El Roble (ICN 12476). Risaralda: Quimbaya, Vereda La Suiza (UV 12694). Santander: Charalá, Margen derecha del Río Guillermo, inspección de policía Virolín (ICN 8150). Tolima: Cajamarca, Vereda Peñaranda parte Baja (CZUT-M 58). Vereda Planadas (CZUT-M 83, 84, 144, 145). Vereda EI salitre (CZUT-M 208, 317). Ibagué, Vereda Toche (CZUT-M 57). Quebrada La Plata (CZUT-M 206, 207). Valle del Cauca: Buga, Vereda El Janeiro (UV 12402 to 12405, 12407, 13022, 13023). 